\title{
Tourism Industry: Development and Importance of Foreign Economic Relations of Russia
}

\author{
Elena I. Ohrimenko \\ Ural State University of Economics \\ Yekaterinburg, Russia \\ oelenai@yandex.ru
}

\author{
Olga T. Ergunova \\ Ural State University of Economics \\ Yekaterinburg, Russia \\ ergunova-olga@yandex.ru
}

\begin{abstract}
The paper discusses the essential characteristics of the international tourism industry; the importance of the development of regions that influence foreign economic relations has been determined; the comparative dynamics of business tourism and tourism with personal goals development has been shown; comparative analysis of the dynamics of the number of entry business visas and the volume of trade turnover between the most active participants of foreign trade with the Russian Federation has been presented and justified; the essence and importance of foreign economic relations affecting the development of tourism in Russia have been revealed.
\end{abstract}

Keywords-tourist industry; business tourism; tourist activity; development of regions; tourist infrastructure; foreign trade potential; business visas; dynamics; foreign economic relations; competitiveness; world market.

\section{INTRODUCTION}

Today, the Russian Federation (RF) is aimed at developing foreign economic activity not only in various sectors of the economy, but also with as many countries as possible having different economic systems and different business traditions. This fact, on the one hand, is explained by the foreign policy problems in relations with a number of countries that support the anti-Russian sanctions of the West. On the other hand, the positive results of import substitution in some sectors of the Russian economy have increased its competitiveness and foreign trade potential, the implementation of which is also seen in expanding the geography of foreign economic relations.

The identified problem was the basis for the selection of the subject under study and made it possible to determine its relevance.

\section{MATERIALS AND METHODS}

To date, insufficient research regarding the conditions for the functioning of the Russian tourism market, as well as ways to bring the Russian tourism industry out of crisis has been carried out. There is a large number of works by scientists on the place of Russia in the world tourism market, its prospects and opportunities.

The influence of globalization processes on the formation of the Russian business tourism market has been investigated by such authors, as I.I. Afanasyev, V.V. Bikbulatova. The problems and prospects of Russia's competitiveness in the global business tourism market were analyzed in their works by S. S. Duguzhev, P. I. Ananchenkov, K. F. Fam, and others.

The development of foreign economic relations of Russia was considered by A.D. Vasilieva, Ya.S. Testina, A.V. Kuchumov, and others.

The special significance of the tourism industry for the development of foreign economic relations of Russia is indicated and analyzed in the works of T.S. Groznykh and other scientists.

"The global market for tourism services creates demand and supply for the results of the activities of the international tourism industry of the participating countries. In turn, the international tourism industry is a comprehensive system where enterprises - producers of goods and services - act as elements, within the framework of which interaction and mutual influence of various industries [8]". From the information on the website of the Federal Tourism Agency, it follows that the tourism industry stimulates: economic growth through the development of all its industries; development of small and medium-sized businesses; employment and selfemployment; smoothing imbalances in territorial development; improving the quality of life of the population; increase in export volumes; increase in tax revenues to budgets of all levels [13].

\section{RESULTS AND DISCUSSION}

Despite the fact that in the world the share of tourism in gross domestic product (GDP) is estimated at $10 \%$ [17, p. 6], in Russia, the contribution of tourism to the gross domestic product (GDP) is estimated at about 5\% [11] with a slight positive dynamics for 2013-2017 (Figure 1). In addition, the contribution of tourism to the Russian economy is estimated by Rostourism as follows:

- $\quad$ in 2017 , the volume of paid hotel services and similar accommodation facilities amounted to more than $219,915.70$ million rubles (an increase of $3.11 \%$ compared to 2016);

- $\quad$ in 2017 , the volume of paid tourist services to the population is more than $166,520.10$ million rubles (an increase of $3.21 \%$ ) [13]. 
It should be noted that the implementation of the Federal Target Program Development of Domestic and Inbound Tourism for 2011-2018, which involves "creating conditions for improving the quality of life of citizens, including through the development of leisure and tourism infrastructure, as well as ensuring quality, accessibility, and competitiveness of tourist services in the Russian Federation, has been completed.

As the authors note, an important aspect is that in the world, there can be a large number of classification criteria, with which we can describe the diversity of tourism. This is due, firstly, to the already existing diversity of world regions with their own way of life, economy, and, secondly, to the existing needs of people in the knowledge of new information that can be provided to them by certain regions of the world. As a result, it can be stated that tourism is actively involved in the global economy.

The development of tourism infrastructure in the regions is recognized as the most effective for implementation from the point of view of a cluster approach" [5, p. 735]. The implementation of tourism development activities is continuing within the framework of the Concept for the LongTerm Socioeconomic Development of the Russian Federation for the period until 2020. In particular, tourism is defined in the program as "one of the main tools for preserving the cultural and historical heritage, developing cultural and business foreign economic relations, as well as developing regions" [12], which also indicates the high importance of tourism in the development of culture and economy in the Russian Federation.

Note that the importance of tourism in modern market conditions is obvious. So, for example, the interest of the world business community in Yekaterinburg is increasing every year: in 2017, 165 business visits and 88 diplomatic visits took place.

Last year, delegations from China, Italy, Germany, the United Kingdom, and Japan visited Yekaterinburg most actively.

In 2017, the development of Yekaterinburg as a venue for Russian and international events continued. Some of the most significant events are as follows: INNOPROM-2017 International Industry Exhibition (about 50 thousand participants), VIII Eurasian Economic Youth Forum Eurasian Space: Neighborhood and Strategic Partnership (about 15 thousand participants), 100+Forum Russia-2017 International Forum for High-rise and Unique Building (about 7 thousand participants), Cities of Russia 2030: Crossroads of Opportunities All-Russian Forum for Strategic Development (about 1000 participants).

The expansion of international relations and the establishment of business contacts with foreign countries are facilitated by the work of the consular corps accredited in Yekaterinburg.

At the end of 2017, 24 accredited institutions have worked in the city. Yekaterinburg stably retains the third place in the Russian Federation in the number of consular missions and foreign diplomats. At the end of 2017, Yekaterinburg has 14 partner cities. 
International contacts in the field of culture are actively developing. In 2017, the number of major events aimed at developing cultural cooperation has increased by 2 units and amounted to 34 events.

The development of the cultural life of Yekaterinburg in 2017 was greatly facilitated by events organized jointly with the Consulate General of Germany, the Consulate General of Hungary, the Consulate General of the Czech Republic, the Office of the Honorary Consul of Austria, the Institute for Foreign Trade of Italy, the Consulate General of the People's Republic of China.

In recent years, the number of foreign tourists has been growing in Yekaterinburg. This is due to increased recognition of the city in the business and educational tourism market. In 2017, the number of foreign citizens visiting Yekaterinburg has increased by $14.6 \%$ and amounted to 340.1 thousand people. The number of foreign guests visiting Yekaterinburg with tourist purposes has increased by $57.1 \%$ and amounted to 13.2 thousand people [7].

The significance of business tourism can be traced using a comparative analysis of the dynamics of the number of entry business visas issued by the Ministry of Foreign Affairs (MFA) of the Russian Federation and the volume of trade between the most active participants in foreign trade with the Russian Federation (Table 1, Figure 3).

TABLE I. COMPARATIVE ANALYSIS OF THE DYNAMICS OF THE NUMBER OF ENTRY BUSINESS VISAS ISSUED BY THE RUSSIAN MINISTRY OF FOREIGN AFFAIRS AND VOLUME OF COMMODITY TURNOVER BETWEEN THE MOST ACTIVE PARTICIPANTS OF FOREIGN TRADE WITH THE RUSSIAN FEDERATION IN 2016 AND 2017 [9], [10], [14]

\begin{tabular}{|l|l|l|l|l|}
\hline \multirow{2}{*}{ Countries } & \multicolumn{2}{|l|}{$\begin{array}{l}\text { Number of business } \\
\text { visas issued, units }\end{array}$} & \multicolumn{2}{l|}{$\begin{array}{l}\text { Commodity turnover } \\
\text { with Russia, billion } \\
\text { dollars }\end{array}$} \\
\cline { 2 - 5 } & in 2016 & in 2017 & in 2016 & in 2017 \\
\hline 1 & 2 & 3 & 4 & 5 \\
\hline China & 129,110 & 162,899 & 37.41 & 61.40 \\
\hline Germany & 76,554 & 63,117 & 24.95 & 24.64 \\
\hline Finland & 44,351 & 41,587 & 16.13 & 9.76 \\
\hline Estonia & 25,954 & 27,942 & 5.32 & 2.69 \\
\hline Latvia & 27,575 & 26,648 & 13.10 & 7.30 \\
\hline France & 31,006 & 26,419 & 18.30 & 11.66 \\
\hline Italy & 31,446 & 26,282 & 41.70 & 29.90 \\
\hline Lithuania & 33,864 & 23,650 & 4.70 & 3.20 \\
\hline Poland & 33,760 & 22,102 & 23.00 & 13.00 \\
\hline $\begin{array}{l}\text { United } \\
\text { Kingdom }\end{array}$ & 28,401 & 20,906 & 19.50 & 18.57 \\
\hline
\end{tabular}

According to a comparative analysis, the growth in the issuance of business visas to representatives of a country in almost all cases meant an increase in trade between the Russian Federation and the corresponding country (the exception was the Baltic countries - Estonia and Latvia).

The reduction in the number of visas, on the contrary, is an indicator of the forthcoming decline in trade between countries.
At the same time, the authors believe that it is definitely impossible to say that the volume of issuing visas is the main factor influencing the state of business tourism in the country. There are many other factors that have both a positive and negative impact on the development of foreign economic relations of Russia in the framework of the tourism industry.

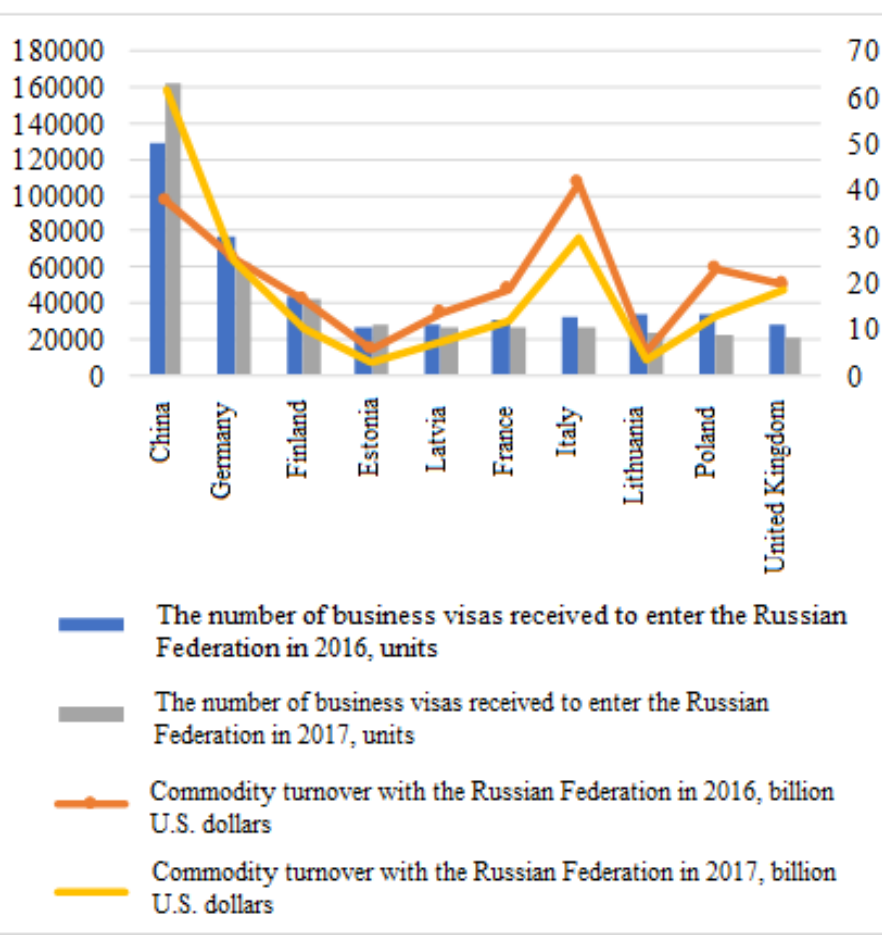

Fig. 3. A comparative analysis of the dynamics of the number of entry business visas issued by the Ministry of Foreign Affairs of the Russian Federation and the volume of trade between the most active participants in foreign trade with the Russian Federation in 2016 and 2017

Thus, it can be argued that the importance of business tourism for the Russian economy is not yet large enough. So, its share in the total number of tourist arrivals is about $22 \%$, and its contribution to the GDP of the Russian Federation is about $5 \%$ instead of $10 \%$, which are recorded on average in the developed countries of the world. However, its contribution to the country's economy is significant due to the fact that an increase in the number of business contacts between Russian and foreign business communities leads to an increase in mutual commodity turnover, and vice versa.

\section{CONCLUSION}

The Russian Federation has a powerful resource potential, the use of which can become a significant factor in the development of tourism services and increase flows of domestic and inbound tourism.

The statistics provided in the paper confirm the significant role of the development of international business tourism for the country's economy. On the part of the State, appropriate measures are necessary to support the development of regions. According to the authors, the development potential of tourism depends on how large the resources of the regions are for the development of tourism and what their condition is: financial, infrastructure, natural, etc. 
[10] International markets. Exporters of Russia. Access regime: http://www.rusexporter.ru/research/country/detail/4863/ (date of appeal: 04.01.2018).

Currently, it is recognized the need to stimulate international business tourism as one of the leading factors in the development of foreign economic relations in the context of a difficult foreign economic and foreign policy situation.

\section{References}

[1] Ananchenkova P. I. Tourist image of destruction (on the example of the Azerbaijan Republic). P. I. Ananchenkov, M. Yu Kuznetsov. Ethnosocium and inter-ethnic culture, 2017. № 7 (109). Pp.152-157.

[2] Athaniev I. I. Trends in the development of international tourism in the context of globalization/I. I. Athaniev, E. A. Klopot, D. B. Serova.

[3] A-factor: scientific research and development (humanities), 2017. № 2. Pp. 9-17.

[4] Bikbulatov E. A. Prospects of Foreign Economic Cooperation between Russia and Georgia. E. A. Bikbulatov, Yu. V. Dmitry, T. L. Bazhenova. International Scientific Journal Innovation Science, 2017. № 5. Pp.8891.

[5] Vasilieva A.D., Testina Y.S., Kuchumov A.V. Development of foreign economic relations between Russia and China in the field of tourism. Scientists notes of the Crimean Federal University named after V.I. Vernadsky. Economics and management. 2018. T.4 (70). № 1. Pp. 3140.

[6] Grozny T.S. The importance of the tourism industry for the development of foreign economic relations of Russia. Internauk. 2018. №44-2 (78). Page 18-20.

[7] Duguzheva S. S. Image of Russia as an object of tourist attractiveness in conditions of crisis. S. S. Duguzheva. Strategy for development of hospitality and tourism industry: Materials of the second International Scientific Student Conference, 2015. Pp. 191-195.

[8] Results of socio-economic development of the municipality "City of Yekaterinburg" in 2017. Department of Economics Administration of the city of Yekaterinburg. Yekaterinburg, 2018. $156 \mathrm{p}$.

[9] Kapulina L.M. Competitiveness of countries in the world market of tourism services [text]: [monograph]/L.M. Kapulina, V.V. Vyazovskaya; The Ministry of Education and Science Ros. Federations, Ural. State ekon. Un-t. Yekaterinburg: [Ural. State ekon. Un-ta], 2017. 166 p. 2.
[11] Russian Foreign Trade Reviews. Russian Foreign Trade. Access regime: http://russian-trade.com/ (date of appeal: 04.01.2018).

[12] Pecherica E. V. Business tourism as a promising direction of development of the economy of the region (on the example of St. Petersburg)/E. V. Pecherica. Modern management technologies 2014: Collection of materials of the international scientific conference, 2014. Pp.733-740.

[13] The order of the Government of the Russian Federation of 17.11.2008 No. 1662-r (an edition of 28.09.2018) "About the Concept of long-term social and economic development of the Russian Federation until 2020" (together with "The concept of long-term social and economic development of the Russian Federation until 2020"). Consultant Plus. Access mode: http://base.consultant.ru/cons/cgi/online.cgi? req=doc; base=LAW; $n=90601$ (date of the address: 20.11.2018).

[14] A tourism role in the Russian economy. Rostourism. - Access mode: tourism https://www.russiatourism.ru/contents/vkartinkah/Rol in the Russian economy (date of the address: 29.12.2017).

[15] Statistics on visas issued by Russian diplomatic missions and consular offices. Consular information portal of the Ministry of Foreign Affairs of $\begin{array}{lll}\text { Russia. } & \text { Access } & \text { regime: }\end{array}$ http://www.kdmid.ru/cons.aspx?lst=cnslfunk\&it=/visa.aspx (date of appeal: 04.01.2018).

[16] Pham K. F. Analysis of the main factors that influenced the economic situation in the Russian Federation in 2015-2016/K. F. Pham, M. P. Lazarev. Economics and business: theory and practice, 2017. № 4-2. Pp.109-112.

[17] Federal Law No. 132-Ф3 dated 24.11.1996 (ed. 04.06.2018) "On the Basics of Tourist Activity in the Russian Federation". Consultant Plus. Access regime: http://www.consultant.ru/document/ cons_doc_LAW_12462/ (date of appeal: 28.10.2018).

[18] Annual Report World Tourism Organization 2016. Madrid (Spain): World Tourism Organization (UNWTO). 2017. 78 p.

[19] Tourism Statistics//UNWTO E-library - Access mode: https://www.eunwto.org/toc/unwtotfb/current (date of appeal: 20.01.2018). 